\title{
Religion and technological development in China and Europe between about 700 and 1800
}

\section{Karel Davids}

\section{OpenEdition}

\section{Journals}

\section{Electronic version}

URL: http://journals.openedition.org/artefact/500

DOI: 10.4000/artefact.500

ISSN: 2606-9245

\section{Publisher:}

Association Artefact. Techniques histoire et sciences humaines, Presses universitaires du Midi

\section{Printed version}

Date of publication: 1 October 2016

Number of pages: $287-298$

ISBN: 978-2-7535-5174-9

ISSN: 2273-0753

\section{Electronic reference}

Karel Davids, "Religion and technological development in China and Europe between about 700 and 1800 », Artefact [Online], 4 | 2016, Online since 07 July 2017, connection on 20 April 2019. URL : http:// journals.openedition.org/artefact/500; DOI : 10.4000/artefact.500 


\section{Religion and technological development in China and Europe between about 700 and 1800}

Karel DAVIDS*

\section{Résumé}

Le développement technique a de plus en plus divergé entre Chine et Europe après 1500. Cet article soutient qu'on ne peut pas seulement expliquer cette divergence par des variables économiques comme les prix du combustible et de la main-d'œuvre. Sont également intervenues des variations dans les contextes religieux en Chine et en Europe. Mais, contrairement aux considérations de nombreux historiens et théologiens, le facteur-clé ne peut pas être trouvé dans les différences de croyances et de valeurs dans les traditions religieuses. Plus pertinentes ont été les différences dans l'influence des institutions religieuses et dans le rôle des communications et des mouvements de personnes imputables aux traditions religieuses. Ces aspects de la religion ont contribué à des disparités dans la formation des hommes, la circulation des connaissances et l'innovation technique entre Chine et Europe qui se sont manifestées après 1500 .

Mots-clés : circulation des connaissances, formation, innovation technique, institutions religieuses, traditions religieuses.

\section{Abstract}

The development of technology in China and Europe increasingly diverged after about 1500. This article argues that this divergence can not only be explained by economic variables such as relative prices of fuel and labour. Variations in religious contexts in China and Europe mattered too. Contrary to views of many historians and theologians, however, the key factor cannot

*. Karel Davids is Professor of Economic and Social History at the Vrije Universiteit Amsterdam, The Netherlands. His main fields of interest are global history, history of technology, history of knowledge and maritime history. Recent major publication : Religion, Technology and the Great and Little Divergences. China and Europe Compared, c. 700-1800, Leiden/Boston, Brill, 2013. 
be found in differences in beliefs and values in religious traditions. More relevant were differences in the impact of religious institutions and in the role of communications and movements of people related to religious traditions. It is argued that these aspects of religion contributed to disparities in human capital formation and circulation of knowledge as well as technical innovation between China and Europe that became manifest after 1500.

Keywords: circulation of knowledge, human capital formation, religious institutions, religious traditions, technological innovation.

\section{Comparing technology in China and Europe}

Until the early nineteenth century, technological developments in China and Europe showed similarities in many respects. Both China and Europe saw long periods of incremental technological change, interspersed with eruptions of more intense innovative activity ${ }^{1}$. The fact that technological breakthrough eventually occurred in Europe and not in China should not lead us to exaggerate differences in the level or direction of technological change in Europe and China before 1800 .

Take for example the variety of machines and implements used in China and Europe. In his famous Science and civilisation in China, Joseph Needham listed a wide range of wooden or bamboo devices with revolving or spinning components, powered by animals, humans or water, which were employed to carry out certain productive functions in agriculture, mining or industry in China before the nineteenth century. Among these machines were querns, animalpowered grinding mills, hand-driven chain pumps, scoop-wheels moved by humans or animals for lifting water into fields, winches for mine-shafts, humandriven winnowing-fans, water-powered bellows, water-driven multi-spindle spinning frames and vertical two-roller sugar cane crushers powered by animals $^{2}$. All the different types of machines and mechanical devices described in Needham's work could also be found in late medieval and early modern Europe, although they were not always made of the same sort of materials. China and Europe did not profoundly diverge in the orientation of technological change either. The approach is now slightly different among historians. Using a distinction introduced by Francesca Bray, Bozhong Li suggested that technologies in China were "skill-oriented", whereas technologies in Europe were « mechanical». Mechanical technologies « favour the development of equipment and machinery as a substitute for human labour ", skill-oriented technologies " tend towards the development and intensive use of human skills, both practical and managerial ${ }^{3} »$. But granted that Europe in " mechanical " technologies followed a more consistent trajectory than 
China, the economically most advanced parts of Europe, such as the Netherlands, throughout the early modern period nevertheless also continued to make great strides in "skill-oriented » technologies. ${ }^{4}$ Qing China also saw the adoption of labour-saving improvements; in other words, China did develop and used " mechanical » technologies ${ }^{5}$. Therefore, the distinction between " mechanical» and « skill-oriented » thus does not neatly map on the distinction between Europe and China.

Yet, despite these similarities in the level and direction of technological change, important differences between China and Europe emerged as well, especially from about 1500 onwards. Technological development in China focused on different sectors than in Europe. In contrast with Mark Elvin's thesis that late Ming and Qing China suffered from « a relative technological standstill » due to a combination of high agricultural productivity, nearly static markets and cheapening labour (" the high-equilibrium trap $»)^{6}$, historians of China recently have argued that Qing China still witnessed significant technological advance. What is striking, though, is that they lay more emphasis on changes in the agricultural sector than on innovations in urban industries or in maritime transport. To establish that Qing China did see technological change, scholars seem to overwhelmingly draw attention to the diffusion of new crops (such as sweet potatoes or maize) and of new varieties of rice, to the spread of new ways of tilling the soil and to the dissemination of various improvements in cropping systems, fertilizer use or sugar processing techniques ${ }^{7}$. In industry, silk production and porcelain manufacture are highlighted as sectors in which China for a long time was more advanced than Europe $^{8}$. On the other hand, the demand for skills of Jesuit missionaries at the Qing court in the eighteenth century suggests that the Chinese could learn something from Europeans as well. Qing emperors valued Jesuits not only for their knowledge of astronomy and mathematics and their expertise in building machines and in making clocks, automata and scientific instruments, but also for their abilities in a wide range of other specialties: they supervised, notably, the founding of cannon, they participated in surveys of the empire, they produced maps, they made oil paintings, they led operations in glass making, they designed fountains, gardens and palaces and they introduced new plants and medicines .

Moreover, the potential of specific techniques and artefacts that were known both in China and in Europe was not always as fully realized in the former region as in the latter ${ }^{10}$. Clocks, cannon, the magnetic compass and printing by movable type are perhaps the best-known cases in point, but they are by no means the only ones. Other examples are the multi-spindle spinning machine, which was known in China as early as the fourteenth century but in contrast with Europe was not adopted in cotton spinning ${ }^{11}$, or the vertical tworoller sugar cane crusher, powered by animals, which entered China in the seventeenth century at about the same time as European plantation colonies in the Americas, but did not evolve into the even more productive animal-driven or water-driven three-roller type ${ }^{12}$. 
Technology in use in China and Europe thus could differ more than a survey of technological potential may suggest.

At the end of the day, it was Europe, not China, where the transition to a modern industrial economy began and sustained economic growth took off. The beginning of modern economic growth is nowadays widely seen as a result of a dramatic shift in energy basis, which allowed an unprecedented rise in energy consumption and a huge increase in productivity. This change in energy basis, which essentially revolved on a large- scale transition from the use of energy from sources above the surface of the earth (such as timber) to energy derived from sources stocked below the surface of the earth (such as fossil fuels) implied a fundamental transformation in the relation between human societies and the natural environment ${ }^{13}$. By shifting to this new energy regime from the late eighteenth century onwards, Europe set out on an entirely different path of economic and technological development than China and the rest of the world.

\section{Explaining variations in technological change}

Where did these variations in technological change between China and Europe come from? Some historians seek an explanation in proximate causes, such as relative factor prices. Robert Allen, for example, argues that whereas in eighteenth-century Britain the high cost of labour compared to energy was a powerful incentive to substitute fuel for labour, no such stimulus worked in China, because access to fuel was expensive relative to labour ${ }^{14}$. However, explanations based on proximate causes do not make clear why technological change in China and Europe differed by sector, or even more importantly, how knowledge was created and where it came from. To answer such questions, we have to probe into more fundamental factors that affect technological development. One of the underlying factors that needs further scrutiny is the relationship between technology and religion.
David Landes noted that various scholars have sought the explanation for the European' "invention of invention " in a particular set of religious values, such as the "Judeo-Christian" " respect for manual labor », «the subordination of nature to man " and "sense of linear time ", although he himself preferred to seek the ultimate cause in market forces ${ }^{15}$. Rolf Sieferle likewise included religious factors among the relevant circumstances that made the eventual industrial transformation in Europe possible $^{16}$. Joel Mokyr observed that « religion, technology and society were often intertwined in ways that defy easy generalization but that had an evident effect on technological creativity ${ }^{17}$ ».

When Western scholars rediscovered the full scale of past Chinese achievements in technology, the issue of the religious context of technological development also became an issue in 
the historiography on China ${ }^{18}$. Joseph Needham suggested that especially Daoism, and to a lesser extent Buddhism, offered a highly favourable environment for the development of particular techniques, notably in chemistry, medicine and dietetics. Confucianism, in contrast, showed a much more reserved attitude towards technological innovation; and it was Confucianism, reshaped as « NeoConfucianism » under the Southern Song period (960-1279) that eventually became the dominant value-system in the Chinese State ${ }^{19}$.

Regarding Europe, R.J. Forbes, Lynn White, Carl Amery, Ernest Benz and other historians of technology, historians of religion, and theologians have insisted that the beliefs and values of Christianity, especially in Latin Christendom, exerted a significant influence on the development of technology ${ }^{20}$. In its general form, the argument runs that Christianity and/or the organized Church paved the way for technological advance by creating a sharp distinction between man and nature. Because Christianity is said to place man above the rest of physical creation, while denying rivers, trees or hills their own "spirits " and refusing to accept the view of the cosmos as a living organism, it is supposed to have laid the basis for a more domineering and conquering attitude on the part of humans towards the natural world. It was easier to manipulate nature once nature supposedly had lost its soul.

To assess the merits of such claims about the relation between religious contexts and technological change, it is necessary to start by recognising that religion is a multi-faceted phenomenon, which finds expression in people's beliefs, practices and experiences, in institutions and in media, as well as in rituals, images and doctrines. Sociologist of religion Steve Bruce offers the following definition that, in his view, « fits with broad contemporary common-sense reflection on the matter »: « Religion... consists of beliefs, actions, and institutions, which assume the existence of supernatural entities with powers of action, or impersonal powers or processes possessed of moral purpose $^{21}$. » Charles Taylor concurs, provided one keeps in mind that the line of demarcation between the natural and the supernatural is drawn less sharply in non-Western cultures and can change in the course of time $e^{22}$.

Using this broad concept of religion as guidance, let us to examine to what extent disparities in the evolution of technical knowledge between Europe and China can be explained by differences in religious context? Starting with beliefs and values about relations between man and nature, I will next move via the domains of institutions, patterns of communication and movements of people to the field of practices and experiences where the actual technological innovation occurs. 


\section{Religious traditions and visions of nature}

Contrary to what many authors have claimed, differences in religious beliefs and values cannot explain differences in technological development. Religious traditions do not consistently offer a particular vision of nature that may explain why humans are more, or less, prepared to exploit the natural environment for their own uses. Latin Christianity in fact did not always and everywhere condone the ruthless domination of nature. The Bible allows a variety of interpretations concerning the way humans should treat the natural world. Both exploitation and stewardship can be justified with a reference to Holy Scripture. There is no evidence that the Latin Church, or Christians in Western Europe in general, from the Middle Ages onwards only adhered to an interpretation that vindicated an exploitative attitude to nature ${ }^{23}$.

Religious traditions in China did not show a consistent bias in one direction or another either. Robert Weller observed that most visions of nature in China are "perfectly comfortable with manipulating natural forces for human benefit ", even though the forms taken by these visions could vary widely. ${ }^{24}$ In this respect, Confucian, Daoist or Buddhist traditions differed less than Needham supposed. Derek Bodde distinguished seven approaches to nature in the history of China, ranging from rejection via exploitation, analysis and animistic and moralistic views to a total, mystical union with the natural world. These approaches were neither mutually exclusive nor solely linked to particular religious traditions ${ }^{25}$. The idea that in Chinese thought, « man » and « nature » have always been viewed as a seamless whole and that harmony with nature has invariably been seen as the ultimate ideal, turns out to be largely a construction of twentieth-century scholars ${ }^{26}$. Seeking explanations for differences in technological development in variations in religious beliefs and values thus seems to lead to a dead end.

\section{The impact of differences in religious context in China and Europa}

Still, variations in religious context did matter for the divergence in technology between China and Europe, but in other ways than many a historian or theologian has imagined. Differences in religious institutions and in patterns of communications and movements of people related to religious traditions were much more important than differences in beliefs and values. These very factors in the course of time contributed to disparities in human capital formation, circulation of knowledge and technical innovation.

The relations between governments, markets and religious institutions in China and Europe developed along different paths. In China, the balance between these three forces in the field of technology from the Song period (9601279) onwards tilted heavily towards the central government. The reduction of the weight of religious institutions was only partly compensated by the expanding share of the role played by markets. While in Europe, the weight of governments and markets in human capital formation, circulation of knowledge 
and the creation of new technologies had substantially increased from the High Middle Ages (fith-tenth centuries) onwards, too, religious organizations, in particular those of the Catholic Church, continued to have a strong impact in all three areas as well.

Religious institutions in China from the Song period onwards were increasingly relegated to a subordinate position both in informal and formal learning. « Informal » learning includes learning by using and learning by doing, formal learning comprises learning by schooling or by institutions for research and development. Under the Song, Buddhist monasteries for example gradually lost the importance as leading centres of education and printing which they enjoyed during much of the Tang period $(618-907)^{27}$. In Latin Christendom, by contrast, monasteries and church building sites, especially between c.1100 and 1500 , offered craftsmen plenty of opportunities for informal and formal learning and thus aided human capital formation. Before 1500, religious institutions in Europe did not only make a much larger contribution to the supply of formal education than state governments, but they continued to be significant suppliers of educational facilities even after secular governments and commercial entrepreneurs entered the field. From the sixteenth century onwards, religious institutions, especially in Spain, Italy, France and other Catholic regions, made a remarkable comeback in elementary, secondary and higher education. In many places in Europe, they were at the forefront of the development of vocational and technical training.
For example, Colbert's grand scheme to endow France with royal chairs in navigation in Le Havre (1660) and Nantes (1672) and the establishment of training colleges for naval officers in Brest, Rochefort and Toulon (1682) could only be realized thanks to the new religious organizations that arose during the Catholic Reformation. Many teaching posts at the newly-created schools were filled by members of the Society of Jesus. Some of the posts were even established in Jesuit colleges, although the courses could also be attended by external pupils. Jesuits were very active in the spread of nautical knowledge in France ${ }^{28}$.

Religious organizations in France also became involved in technical education at an intermediate level ${ }^{29}$. The most active organization in this field was the congregation of the Brothers of the Christian Schools, which was founded by Jean-Baptiste de la Salle in 1680. In the eighteenth century, the Frères des Écoles Chrétiennes set up navigation schools in Vannes and Nantes and a school of commerce at Boulogne, offered courses in drawing and geometry in inland towns such as Cahors and Castres, and established boarding schools combining instruction in applied sciences with vocational training for careers in surveying, accounting, navigation and government service in a dozen cities and towns in various parts of France. There was never a shortage of applicants. At the level of primary schooling, charity companies within parishes, founded under the impulse of the Catholic Reformation after 1650, and the Frères des Écoles Chrétiennes provided free education in reading, writing, arithmetic and other skills for children from poor fami- 
lies, as preparation for their guild-supervised period of apprenticeship ${ }^{30}$.

Moreover, circulation of technical knowledge was in Europe to a greater extent bound up with religious institutions, rituals and practices than in China. Religious travelling served as a channel for flows of technical knowledge from the High Middle Ages onwards. Aside from the widespread practice of pilgrimage, which had a counterpart in journeys to temple fairs or birthday celebrations of local deities in China, the rise of networks between monastic houses in Europe was especially important. Filiation relationships between monasteries in the Cluniac and in the Cistercian networks and institutional arrangements for visitation and mutual consultation, facilitated for example the diffusion of innovations in hydraulic technology. As demonstrated by Roberta Magnusson, the Cistercians even « seem to have had something of a policy of sending out architects to help instruct the members of new foundations ${ }^{31}$ ». In 1133, Saint Bernard of Clairvaux sent a senior monk from his monastery to a new community in Fountains to instruct its members not only in Cistercian customs, but also in architecture and the craft of plumbing $^{32}$. Religious houses, in their turn, " functioned as vital communication channels of the diffusion of awareness » of innovations in hydraulic technology to medieval townsmen ${ }^{33}$. Similar institutionalized patterns of knowledge circulation between Buddhist or Daoist monasteries in China does not seem to have existed.

Reform movements in the Catholic Church further stimulated the accumulation and circulation of technical knowledge from the sixteenth century onwards. Organizations that battled in the forefront of the educational and missionary campaigns of the Catholic Reformation, such as the Society of Jesus, often were also very active in creating sites for the collection and storage of technical information, such as libraries, gardens, curiosity cabinets, model collections and museums. Missionary fervour moreover gave a powerful boost to long-distance travel by Europeans, which added massively to the flows of knowledge between Asia, the Americas and Europe. Jesuits transmitted precious information on Chinese technologies (such as porcelain-making) to Europe and even continued to do so after their Society, under pressure from Catholic states, had been dissolved by the Pope in $1773^{34}$.

Technical innovation, too, was influenced by religious contexts. Before about 1500, religious institutions both in China and in Europe formed a friendly environment for innovations. The rise of woodblock printing in China from the eighth century onwards, for example, was closely connected with Buddhist monasteries and the reproduction and diffusion of sacred images and texts.

The boom in temple construction from the Tang dynasty to the Yuan dynasty (1279-1368) made a major contribution to the perfection of a system of building large structures with standardized parts. Temples were repeatedly rebuilt, refurbished or adorned with pagodas. While newly-built temples under the Song or Yuan were sometimes affiliated with a Buddhist or Daoist school or movement, they were often devoted to the cult of some local or supra-local deity, in which 
« ritual masters » from different traditions could be involved. These temples were affiliated to a senior temple according to a specific hierarchy. Peasants from several villages joined in worshiping societies that built a common temple, devoted to a local deity. Small, rural temples were in turn subordinated to a major temple in a nearby market town, which was often erected by a rich landowner or a merchant. Richard von Glahn had drawn a direct parallel between what happened in China and Europe: "Rising market towns of the Yangzi Delta bore a close resemblance to the cathedral towns of contemporary Europe. In both cases, the towns' affluence was inseparable from the magnificence of their religious monuments ${ }^{35}$.»

In Europe, building sites of cathedrals during the Middle Ages effectively functioned as laboratories of innovation in construction techniques. Temples in China and monasteries in Europe moreover pioneered the development of new techniques in water supply ${ }^{36}$. But were these booms in church and temple building in Europe and China of equal importance for informal learning? The great age of temple-building in China did not last as long as the boom in churchbuilding in Europe. The Chinese building boom by and large came to an end in the middle of the fourteenth century, when the empire was severely shaken by internal conflicts and when the newly established Ming dynasty prevailed and began to clamp down on all manifestations of religious life that did not conform with the newly-propagated cult of the state. As a result of this stringent unifying policy, the number of Buddhist and Daoist temples and shrines drama- tically declined. The building drive of great churches in Europe, by contrast, continued right into the mid-eighteenth century. St Peter's Basilica in Rome and St Paul's Cathedral in London, to mention just two examples, were not completed until the second half of the seventeenth century ${ }^{37}$.

Thus the relation between innovation and religious contexts in China and Europe began to diverge after 1500. The crucial difference was that in China technical innovation to a much greater extent than in Europe took place outside the context of religious institutions. Technological change under the Ming and Qing (1644-1912) became increasingly dependent on the support from the state. Technological development in silk manufacture, salt production in Sichuan, porcelain making in Jingdezhen or water management in the Yangzi Delta, for example, largely took place under the impetus and supervision of public officials and the central government ${ }^{38}$. Although great inventors could be honoured with a shrine or a biography, material incentives for individuals to invent new things did not exist. A market demand for the services of technical experts like architects or engineers hardly emerged. China knew a large number of engineers, but they were mainly active as government employees $^{39}$.

In Europe, secular actors and institutions became progressively more important in technological innovation from the Late Middle Ages onwards. The expansion of the market economy, the rise of urban noble courts and the growth of patronage by secular governments created a range of opportunities for 
resourceful technical practitioners and artisans. Governments introduced incentives for innovation, such as patents, which consisted both of individualized rewards and provisions to benefit the community at large. Religious organizations thus gradually lost ground to other types of actors and institutions.

In contrast with China, however, the context for technological innovation after 1500 did not become purely secular. This was especially the case in parts of Europe that remained predominantly Catholic, such as Italy, France, the Iberian Peninsula, Austria and Southern Germany. A variety of institutions and actors facilitated or promoted technological innovation, including not only princes, dukes, noblemen, cities, merchants and craft guilds, but also religious orders, bishops and popes. In the sixteenth and seventeenth centuries, religious institutions in Europe contributed much more to innovation than temples or monasteries in China during the same period. And the best example can be found in the heart of Latin Christendom, papal Rome.

After the papacy finally re-established its seat in Rome in the early fifteenth century, ecclesiastical authorities embarked on a huge, long-term project of extending, reconstructing and beautifying the city. This vast, religion-inspired urbanist programme ranged all the way from improvement of public utilities and restructuring of public space to the erection of imposing monuments and the construction of glorious residences and magnificent religious buildings. Legions of craftsmen, artists, architects and engineers, supervised by a steadily growing papal bureaucracy, provided the expan- ding city with a myriad of new streets, squares, fountains, fortifications, gates, bridges and river embankments ${ }^{40}$. Public spaces were adorned with statues and monuments reflecting the bonds between papal Rome, Antiquity and Eternity. Erecting these structures and artefacts often involved extraordinary and innovative feats of engineering. The removal of the Vatican obelisk to a position in the square facing the new St Peter's Basilica in 1585-1586, under the supervision of architect-engineer Domenico Fontana and with the help of hundreds of men and horses powering dozens of winches and pulleys, was a first-rate technological achievement, publicized and studied all over Europe during the late sixteenth and seventeenth centuries $^{41}$. Roman buildings like the Jesuits' Gesù were an inspiration for the design of Catholic churches in many places in Europe, the Americas and Asia. The city of Rome attracted large numbers of pilgrims and non-religious travellers such as mathematician John Wilkins and architect Inigo Jones from England. An estimated 30.000 pilgrims visited the city in a normal year, and some 100.000 in a Jubilee Year, which from 1450 took place once every 25 years $^{42}$. Many Europeans thus could see this " model city " with their own eyes. The influence of achievements in Rome extended far into the world. 


\section{Epilogue}

The technological trajectories of China and Europe increasingly diverged after about 1500. This divergence in technological development cannot only be explained by economic variables such as relative prices of fuel and labour. Variations in religious contexts in China and Europe mattered as well. Contrary to ingrained convictions among many historians and theologians, however, the key factor cannot be found in differences in beliefs and values in religious traditions. Both in China and in Europe, visions of nature in religious traditions in fact covered the entire spectrum from exploitation to harmony with the natural environment. What proved to be more relevant, were differences in the impact of religious institutions and in the role of communications and movements of people related to religious traditions. It were these aspects of religion rather than beliefs and values, which contributed to the disparities in human capital formation, circulation of knowledge and technical innovation between China and Europe that became manifest after 1500 .

\section{Notes}

1. Joel MoKyr, The lever of riches. Technological creativity and economic progress, Oxford, Oxford University Press, 1990, p. 7, 57-58, 209-219.

2. Joseph Needham, Science and civilisation in China, vol. IV Physics and physical technology, part 2, Mechanical engineering, Cambridge, Cambridge University Press, 1965, esp. table 56.

3. Bozhong Li, Agricultural development in Jiangnan 1620-1850, New York, St. Martin's Press, 1998, p. 167-168; Francesca BRAY, The rice economies. Technology and development in Asian societies, Oxford, Oxford University Press 1986, p. 115, 156.

4. Karel Davids, The rise and decline of Dutch technological leadership. Technology, economy and culture in the Netherlands, Leiden, Brill, 2008, chapter 3.
5. L. Bozhong, Agricultural development, op. cit., p. 54; Sucheta MAzumdar, Sugar and society. Peasants, technology, and the world market, Cambridge Mass., Harvard University Press 1998, p. 188, 190; Françoise SABBAN, "L'industrie sucrière, le moulin à sucre et les relations sino-portugaises aux $\mathrm{XVI}^{\mathrm{e}}$ XVIII ${ }^{\mathrm{e}}$ siècles ", Annales. Histoire, Sciences sociales, 49, 1994, p. 857.

6. Mark ELvin, The pattern of the Chinese past. A social and economic interpretation, Stanford, Stanford University Press, 1973, p. 301, 312-315.

7. L. Bozhong, Agricultural development, op. cit., p. 39-54; S. MAzUMdAR, Sugar and society, op. cit., p. 138-191; Kent DeNG, « A critical survey of recent research in Chinese economic history ", Economic History Review, 53, 2000, p. 15.

8. Benjamin A. Elman, On their own terms. Science in China, 1550-1900, Cambridge Mass., Harvard University Press, 1995, p. xxxI.

9. Joanna WALEY-COHEN, The sextants of Beijing. Global currents in Chinese history, New York, W.W. Norton, 1999, p. 105-121; Emily Byrne CurTis, Glass exchange between Europa and China, 1550-1800. Diplomatic, mercatntile and technological interactions, Aldershot, Ashgate, 2009, p. 36-37, 41-53, 60-61, 113117; Marco Musillo, « Reconciling two careers. The Jesuit memoir of Giuseppe Castiglione lay brother and Qing imperial painter ", Eighteenth-Century Studies, 42, 2008, p. 45-59.

10. J. Mokyr, Lever of riches, op. cit., p. 218.

11. Kang CHAO, The development of cotton textile production in China, Cambridge Mass., Harvard University Press, 1977, p. 59, 63.

12. S. MaZumdar, Sugar and society, op. cit., p. 138159, 178-180; F. SABBAN, art. cit., p. 824-831; Joseph NeEDHAm et al., Science and civilisation, VI, Biology and biological technology, part 3, Agro-industries: Sugarcane technology, Cambridge, Cambridge University Press, 1996, p. 335.

13. Rolf Peter SIEFERLE, Das unterirdische Walt. Energiekrise und Industrielle Revolution, Beck, Munich, 1982, p. 144-171; id., Der Europäische Sonderweg. Ursachen und Faktoren, Stuttgart, Breuninger, 2003, p. 30, 33, 38; E. A. Wrigley, Continuity, chance and change. The character of the Industrial Revolution in England, Cambridge, Cambridge University press, 1988, p. 17-33; Paolo Malanima, « Energy crisis and growth 1650-1850: The European deviation in a comparative perspective ", Journal of Global History, 1, 2006, p. 101-121.

14. Robert C. Allen, The British Industrial Revolution in global perspective, Cambridge, Cambridge University Press, 2009, p. 140. 
15. David S. LANDES, The wealth and poverty of nations, London, Abacus, 1999, 58-59; Patrick K. O'BrIEN, « The Needham question updated: A historiographical survey and elaboration ", History of Technology, 29, 2009, p. 7-28, likewise draws attention to the differences in "cultures and cosmologies for innovation ", including religious traditions, p. 10, 13-22.

16. R.P. SiefERLE, Der Europäische Sonderweg. Ursachen und Faktoren, op. cit., p. 50.

17. J. МокуR, Lever of riches, op. cit., p. 172.

18. See the classic study by M. ELviN, The pattern of the Chinese past, op. cit., parts two and three.

19. J. Needham, Science and civilization, vol. II, History of scientific thought, Cambridge, Cambridge University press, 1956, p. 33, 131, 76-77, 496, 504-505; id., Science in traditional China, Cambridge Mass., Harvard University Press, 1981, p. 15, 25, 29.

20. Their arguments are summarized in Karel DAvids, Religion, technology and the Great and Little Divergences. China and Europe compared, c. 700-1800, Leiden, Brill, 2013, p. 18-21.

21. Steve BRUCE, Religion in the modern world. From cathedrals to cults, Oxford, Oxford University Press, p. 7.

22. Charles TAYlor, A secular age, Cambridge Mass., The Belknap Press, 2007, p. 429.

23. K. Davids, Religion, technologie, op. cit., p. 34-39.

24. Robert P. Weller, Discovering nature. Globalization and environmental culture in China and Taiwan, Cambridge, Cambridge University Press, 2006, p. 40.

25. Derek Bodde, Chinese thought, society and science. The intellectual and social background of science and technology in pre-modern China, Honolulu, University of Hawaii Press, 1991, p. 309-332.

26. Heiner Roetz, Mensch und Natur in alten China, Frankfurt am Main, Peter Lang, 1984, part I, p. 30-49.

27. K. DAvids, Religion, technologie, op. cit., p.77-79.

28. A. Anthiaume, Évolution et enseignement de la science nautique en France et principalement chez les Normands, Paris, Ernest Dumont, 1920, vol. II; Roger Chartier, Marie-Madeleine Compère and Dominique JulIA, L'Éducation en France du XVI au XVIII siècle, Paris, Société d'éducation d'enseignement supérieur, 1976, p. 228.

29. Laurence BROCKLISs, French higher education in the seventeenth and eighteenth centuries. A cultural history, Oxford, Oxford University Press, 1987, p. 26-27.

30. André Prévot, L'enseignement technique chez les Frères des Écoles chrétiennes au XVIII et au XIX siècles, Paris, Faculté des Lettres et des Sciences humaines, doctorat, 1963, p. 15-19, 42-60; R. ChARTIER, M.-M. Compère and D. Julia, L'Éducation, op. cit., p. 225-227; John McManners, Church and society in eighteenth century France, Oxford, Oxford University Press, 1998, p. 529-532; Clare CRowston, « From school to workshop: Pre-training and apprenticeship in Old Regime France ", in Bert DE MuncK, Steven L. KAPLAN and Hugo Soly (eds.), Learning on the shop floor, New York, Berghahn Books, 2007, p. 46-62.

31. Roberta J. Magnusson, Water technology in the Middle Ages. Cities, monasteries and waterworks after the Roman Empire, Baltimore, The John Hopkins University Press, 2001, p. 13.

32. Ibid., p. 11-13, 17.

33. Ibid., p. 18-19.

34. K. DAvids, Religion, technologie, op. cit., p. 155-158, 164-169; Frasie Hertroijs, Hoe kennis van China naar Europa kwam. De rol van jezuïeten en VOC-dienaren, circa 1680-1795, thèse de l'université d'Amsterdam, 2014, p. 48-62, 196-224.

35. Richard von GLAHN, « Towns and temples: Urban growth and decline in the Yangzi Delta, 11001400 ", in Paul J. SMITH and Richard voN GLAHN (eds.), The Song-Yuan-Ming transition in Chinese history, Cambridge, Cambridge University Press 2003, p. 176-211, 189-196; Valerie HANsEN, Changing gods in medieval China, 1127-1276, Princeton, Princeton University Press 1990, p. 9-10, 57, K. DAvids, Religion, technologie, op. cit., p. 104-105.

36. K. DAvids, Religion, technologie, op. cit., p. 175177.

37. R. Von Glahn, "Towns and temples », art. cit., p. 208-211; K. DAvids, Religion, technologie, op. cit., p. 105-108.

38. K. Davids, Religion, technologie, op. cit., p. 183184; Dagmar SCHAEFER (ed.), Cultures of knowledge: technology in Chinese history, Leiden, Brill, 2012, Hans-Ulrich Vogel, "Technische Entwicklungen und ihre Grenzen im Salzgewerbe von Furong, Sichuan, 17.-19.Jahrhundert ", Orientierungen, 2, 1991, p. 89-119.

39. K. Davids, Religion, technologie, op. cit., p. 183, 187-188.

40. Loren PARTRIDge, The Renaissance in Rome 1400-1600, London, Calmann \& King, 1996, p. 20-26; Pamela O. LoNG, "Hydraulic engineering and the study of Antiquity: Rome, 1557-1570 », Renaissance Quarterly, 61, 2008, p. 1098-1138; Antonella Romano (ed.), Rome et la science moderne entre Renaissance et Lumières, Rome, École française de Rome, 2008.

41. Jonathan SAWDAY, Engines of the imagination. Renaissance culture and the rise of the machine, London, Routledge, 2007, p. 59-68.

42. L. PARTridge, The Renaissance Rome, op. cit., p 16; J. SAWDAY, Engines of the imagination, op. cit., p. 67-68. 